\title{
Perspective \\ Landscape Epidemiology of Xylella fastidiosa in the Balearic Islands
}

\author{
Diego Olmo ${ }^{1}{ }^{\mathbb{D}}$, Alicia Nieto ${ }^{1}$, David Borràs ${ }^{1}$, Marina Montesinos ${ }^{2}$, Francesc Adrover ${ }^{1}$, Aura Pascual ${ }^{2}$, \\ Pere A. Gost ${ }^{3}$, Bàrbara Quetglas ${ }^{3}$, Alejandro Urbano ${ }^{1}$, Juan de Dios García ${ }^{3} \mathbb{D}_{\text {, María Pilar Velasco-Amo }}{ }^{\text {, }}$ \\ Concepción Olivares-García ${ }^{4}$, Omar Beidas ${ }^{3}$, Andreu Juan ${ }^{3}$, Ester Marco-Noales ${ }^{5}$ D, Margarita Gomila ${ }^{6}$, \\ Juan Rita ${ }^{6}$, Eduardo Moralejo ${ }^{2, *}$ and Blanca B. Landa ${ }^{4, *(D)}$
}

Citation: Olmo, D.; Nieto, A.; Borràs, D.; Montesinos, M.; Adrover, F.; Pascual, A.; Gost, P.A.; Quetglas, B.; Urbano, A.; García, J.d.D.; et al. Landscape Epidemiology of Xylella fastidiosa in the Balearic Islands. Agronomy 2021, 11, 473. https:// doi.org/10.3390/agronomy11030473

Academic Editor: Imre Holb

Received: 27 January 2021

Accepted: 28 February 2021

Published: 4 March 2021

Publisher's Note: MDPI stays neutral with regard to jurisdictional claims in published maps and institutional affiliations.

Copyright: (c) 2021 by the authors Licensee MDPI, Basel, Switzerland. This article is an open access article distributed under the terms and conditions of the Creative Commons Attribution (CC BY) license (https:/ / creativecommons.org/licenses/by/ $4.0 /)$.
1 Serveis de Millora Agrària I Pesquera, Govern Balear, 07009 Palma de Mallorca, Spain; dolmo@semilla-caib.es (D.O.); alicianietolopez@gmail.com (A.N.); dborras@semilla-caib.es (D.B.); fadrover@semilla-caib.es (F.A.); urbano@tragsa.es (A.U.)

2 Tragsa, Empresa de Transformación Agraria, Delegación de Baleares, 07005 Palma de Mallorca, Spain; mmontesi@tragsa.es (M.M.); apascua5@tragsa.es (A.P.)

3 Servicio de Agricultura, Conselleria de Medi Ambient, Agricultura I Pesca, 07006 Palma de Mallorca, Spain; pere.antoni.garcia@gmail.com (P.A.G.); barbaraquetglascalvo@gmail.com (B.Q.); jdgarcia@dgagric.caib.es (J.d.D.G.); obeidas@dgagric.caib.es (O.B.); ajuan@dgagric.caib.e (A.J.)

4 Institute for Sustainable Agriculture, Consejo Superior de Investigaciones Científicas (IAS-CSIC), 14004 Córdoba, Spain; mpvelasco@ias.csic.es (M.P.V.-A.); colivares@ias.csic.es (C.O.-G.)

5 Centro de Protección Vegetal y Biotecnología, Instituto Valenciano de Investigaciones Agrarias (IVIA), CV-315 km 10.7, 46113 Moncada, Spain; marco_est@gva.es

6 Biology Department, University of the Balearic Islands, 07122 Palma de Majorca, Spain; marga.gomila@uib.es (M.G.); jrita@uib.es (J.R.)

* Correspondence: emoralejor@gmail.com (E.M.); blanca.landa@csic.es (B.B.L.)

Abstract: Xylella fastidiosa $(X f)$ is a vascular plant pathogen native to the Americas. In 2013, it was first reported in Europe, implicated in a massive die-off of olive trees in Apulia, Italy. This finding prompted mandatory surveys across Europe, successively revealing that the bacterium was already established in some distant areas of the western Mediterranean. To date, the Balearic Islands (Spain) hold the major known genetic diversity of Xf in Europe. Since October 2016, four sequence types (ST) belonging to the subspecies fastidiosa (ST1), multiplex (ST7, ST81), and pauca (ST80) have been identified infecting 28 host species, including grapevines, almond, olive, and fig trees. ST1 causes Pierce's disease (PD) and together with ST81 are responsible for almond leaf scorch disease (ALSD) in California, from where they were introduced into Mallorca in around 1993, very likely via infected almond scions brought for grafting. To date, almond leaf scorch disease affects over $81 \%$ of almond trees and Pierce's disease is widespread in vineyards across Mallorca, although producing on average little economic impact. In this perspective, we present and analyze a large $\mathrm{Xf}$-hosts database accumulated over four years of field surveys, laboratory sample analyses, and research to understand the underlying causes of $X f$ emergence and spread among crops and wild plants in the Balearic Islands. The impact of $X f$ on the landscape is discussed.

Keywords: disease epidemiology; invasive plant pathogens; landscape disease; pathogen ecology; Pierce's disease; quarantine plant pathogen; vector transmission; Xylella fastidiosa spread

\section{Introduction}

The international plant trade has facilitated the entry of an increasing number of invasive pathogens that threaten crops and forests in Europe [1-3]. Among traded plants, ornamentals have notably contributed to the introduction of exotic pathogens from their native ranges to new biogeographic zones [4]. Pathogens with an endophytic stage are remarkably difficult to detect because they show asymptomatic infections [5]. While many quarantine-listed pathogens are intercepted annually at borders by plant health inspectors, 
an unknown number of asymptomatic plants carrying pathogens and non-catalogued new taxa escape controls [4]. Most of these released pathogens will fail to establish, but in a few cases, discovery of their presence occurs too late when they are already established, causing significant damage to crops and forests. Despite wide scientific consensus on the problem [6], to date, alien invasive pathogens continue to breach biosecurity systems.

The recent detection of the bacterium Xylella fastidiosa $(\mathrm{X} f)$ in Europe illustrates the risks, pitfalls, and potential impacts posed by invasive plant pathogens at crop, landscape, and regional scales. In 1989, the European and Mediterranean Plant Protection Organization (EPPO) listed $X f$ as an A1 quarantine pest in order to protect the European wine industry from Pierce's disease (PD) of grapevines in the USA (EPPO/OEPP 1989). Since then, in spite of some sporadic and unconfirmed reports [7], Europe remained free of the pathogen until 2013, when an outbreak of Xf on olive trees was reported in the Salento region of Italy [8]. This unprecedented massive mortality of olive trees heightened concern about the risk of $X f$ spreading across Europe. As a result, mandatory surveys of EU member states were conducted, revealing that the bacterium had also established itself in Corsica, Provence, the Alpes, and Côte d'Azur in France, and Alicante and the Balearic Islands in Spain [9-11]. The current threat to Europe and the Mediterranean basin has increased after multiple Xf subspecies and genotypes were detected in Italy, France, and Spain [12]. Research carried out in Corsica indicated that the pathogen had likely been established for longer than previously thought [13]. The same conclusion was reached in Mallorca after studying the huge mortality of almond trees that began around 2003 in the east of the island, which had been previously associated with fungal diseases [14]. The likely introductions of the ST1 of subsp. fastidiosa and the ST81 of the subsp. multiplex in Mallorca were traced back to around 1993, based on the reconstruction of the almond leaf scorch disease (ALSD) epidemic using evidence from epidemiology, dendrochronology, and molecular biology [15].

$X f$ in the Balearic Islands exemplifies all the risks posed by invasive plant pathogens: (i) it escaped from biosecurity controls; (ii) it was overlooked due to latency and/or being confused with other diseases; and (iii) was locally present several years before being regulated as a harmful organism in the Annex list of the Council Directive 2000/29/EC. With this perspective, we analyze the data gathered during the four years since the first detection of $X f$ in the Balearic Islands, outlining the main results of this field experiment taking place in the intersection between agriculture and natural plant communities. The experimental scenario is currently quite advanced, and it is possible to evaluate $X f$ impact on the landscape, which enables us to draw some conclusions related to the ecology and epidemiology of $X f$-caused diseases.

\section{Results of Xylella fastidiosa Surveys}

The unexpected detection of Xf on Mallorca in October 2016 prompted the extension of the surveys to the other islands of the archipelago. Between November 2016 and December 2020, a total of 13,610 plant samples were analyzed at the Official Laboratory of Plant Health Service of the Balearic Islands (LOSVIB). Samples were received from three main sources: (i) official monitoring as a consequence of the application of the Commission Implementing Decision (EU) 2015/789 and Commission Implementing Regulation (EU) 2020/1201, applying random sampling to prospecting grids; (ii) within the context of several research projects (see funding projects); and (iii) from cooperatives, farmers, and agricultural extension services. The first group of samples included symptomatic and asymptomatic plants, whereas the second and third group of samples were all symptomatic. These included samples from 453 plant taxa within 96 botanical families and different life forms, i.e., from therophytes to phanerophytes, from crop fields, garden centers and wildlands (Figure 1). In order to obtain a representative picture of the situation, sampling efforts were maintained over time and were as balanced as possible among islands (Figure 1). For this, the total number of samples was programmed in relation to the surface of each island. For instance, although the greatest number of samples analyzed were from Mallorca ( $n=6840$ plants), the ratio of samples per surface was the lowest, 1.98 samples $\mathrm{km}^{-2}$, 
compared to the 8.7 samples $\mathrm{km}^{-2}$ from Ibiza. Economically significant crops such as almond trees (Prunus dulcis), grapevines (Vitis vinifera), orange (Citrus spp.), and olive trees were sampled more frequently resulting in certain bias. However, at the end of the four-year period, the survey covered sufficiently extensive areas and environments of each island to obtain a reliable picture of $X f$ at landscape scale.
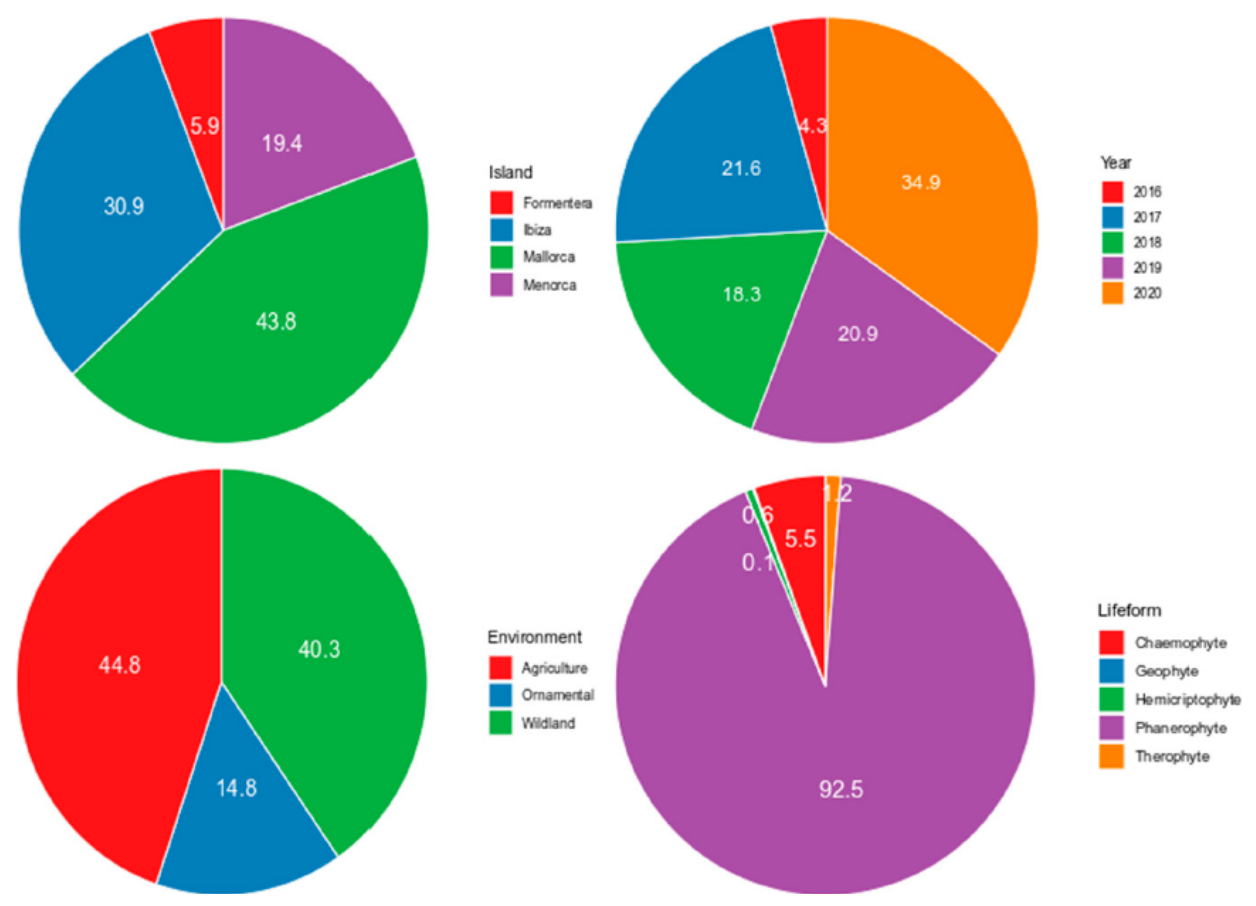

Figure 1. Sampling distribution for Xylella fastidiosa $(X f)$ over time, among islands, different environments, and plant life forms.

In total, $9.05 \%$ of the 13,610 samples across the four main islands, Mallorca, Menorca, Ibiza, and Formentera, tested positive for $\mathrm{Xf}$ by molecular diagnostics tests using realtime/quantitative PCR (qPCR) assays [16,17]. Of these, 28 plant species belonging to 14 botanical families have been identified as hosts (Table 1 ), representing only $6.2 \%$ of the total number of potential hosts analyzed. Four species, Olea europaea, P. dulcis, V. vinifera, and Ficus carica accounted for $60.8 \%$ of all positives. The frequency of $X f$ positives among the three major islands did not vary significantly $(\chi=0.638, d f=2, p=0.73)$. Interestingly, despite intense surveys ( $n=1028$ samples), Xf was not detected on the island of Formentera. All hosts belong to the chamaephytes and phanerophytes Raunkiaer's life-forms classification, which corroborates a preference of $X f$ towards woody plant species [18].

Table 1. List of hosts infected by Xylella fastidiosa in the Balearic Islands updated to December 2020.

\begin{tabular}{|c|c|c|c|c|c|}
\hline Species & Family & $X f$ Subspecies & ST & $\begin{array}{l}\text { Number of } \\
\text { Samples } \\
\text { qPCR+ }{ }^{1}\end{array}$ & $\begin{array}{c}\text { Number of } \\
\text { Samples } \\
\text { Analyzed by } \\
\text { qPCR }\end{array}$ \\
\hline Acacia saligna & Leguminosae & multiplex \& pauca & ST80 \& ST81 & 3 & 48 \\
\hline Calicotome spinosa & Leguminosae & fastidiosa & ST1 & 1 & 18 \\
\hline Cistus albidus & Cistaceae & pauca \& nd ${ }^{2}$ & ST80 \& nd & 4 & 168 \\
\hline Cistus monspeliensis & Cistaceae & fastidiosa & ST1 & 1 & 106 \\
\hline Clematis cirrhosa & Ranunculaceae & multiplex & ST81 & 1 & 13 \\
\hline Ficus carica & Moraceae & multiplex & ST81 & 28 & 421 \\
\hline $\begin{array}{c}\text { Fraxinus } \\
\text { angustifolia }\end{array}$ & Oleaceae & multiplex & ST81 & 7 & 29 \\
\hline
\end{tabular}


Table 1. Cont.

\begin{tabular}{|c|c|c|c|c|c|}
\hline Species & Family & $X f$ Subspecies & ST & $\begin{array}{l}\text { Number of } \\
\text { Samples } \\
\text { qPCR+ }{ }^{1}\end{array}$ & $\begin{array}{c}\text { Number of } \\
\text { Samples } \\
\text { Analyzed by } \\
\text { qPCR }\end{array}$ \\
\hline Genista lucida & Leguminosae & fastidiosa & ST1 & 1 & 6 \\
\hline Juglans regia & Juglandaceae & fastidiosa & ST1 & 1 & 10 \\
\hline $\begin{array}{l}\text { Lavandula } \\
\text { angustifolia }\end{array}$ & Lamiaceae & multiplex & ST81 & 2 & 43 \\
\hline Lavandula dentata & Lamiaceae & multiplex \& pauca & ST80 \& ST81 & 16 & 257 \\
\hline Nerium oleander & Apocynaceae & multiplex \& pauca & nd & 6 & 582 \\
\hline $\begin{array}{c}\text { Olea europaea } \\
\text { europaea }\end{array}$ & Oleaceae & multiplex \& pauca & ST80 \& ST81 & 193 & 1975 \\
\hline $\begin{array}{c}\text { Olea europaea } \\
\text { sylvestris }\end{array}$ & Oleaceae & multiplex \& pauca & ST80 \& ST81 & 495 & 3012 \\
\hline Phagnalon saxatile & Asteraceae & $\mathrm{Nd}$ & nd & 1 & 14 \\
\hline $\begin{array}{c}\text { Phillyrea } \\
\text { angustifolia }\end{array}$ & Oleaceae & multiplex & ST81 & 1 & 50 \\
\hline Polygala myrtifolia & Polygalaceae & multiplex \& pauca & ST7, ST80 \& ST81 & 28 & 219 \\
\hline Prunus avium & Rosaceae & fastidiosa & ST1 & 3 & 48 \\
\hline Prunus domestica & Rosaceae & multiplex & ST81 & 1 & 78 \\
\hline Prunus dulcis & Rosaceae & $\begin{array}{l}\text { multiplex, fastidiosa } \\
\text { \& pauca }\end{array}$ & $\begin{array}{c}\text { ST1, ST7, ST80 \& } \\
\text { ST81 }\end{array}$ & 266 & 1071 \\
\hline Rhamnus alaternus & Rhamnaceae & multiplex & ST81 \& ST1 & 15 & 130 \\
\hline $\begin{array}{c}\text { Rosmarinus } \\
\text { officinalis }\end{array}$ & Lamiaceae & multiplex \& pauca & ST80 \& ST81 & 22 & 830 \\
\hline Ruta chalepensis & Rutaceae & fastidiosa & ST1 & 1 & 8 \\
\hline Salvia officinalis & Lamiaceae & $\mathrm{Nd}$ & nd & 1 & 1 \\
\hline Santolina magonica & Asteraceae & $\mathrm{Nd}$ & nd & 1 & 29 \\
\hline Teucrium capitatum & Lamiaceae & fastidiosa & ST1 & 1 & 62 \\
\hline Ulex parviflorus & Leguminosae & $\mathrm{Nd}$ & nd & 1 & 4 \\
\hline Vitis vinifera & Vitaceae & fastidiosa & ST1 & 134 & 953 \\
\hline
\end{tabular}

${ }^{1}$ Number of samples showing a positive amplification by the qPCR protocols of Harper and Francis [16,17]. ${ }^{2}$ nd $=$ Not determined.

\section{Genetic Diversity and Population Genetics}

Precise identification of $X f$ at an infraspecific level is essential for epidemiological and surveillance analyses, and to allow a proper description of the population structure and dynamics. In addition, the taxonomic placement of Xf strains in Europe is of applied relevance, as European Commission-mandated management strategies are based on the subspecies present in each outbreak. In Europe, the Multi-Locus Sequence Typing (MLST) scheme is used to type the different detections of $X f$ at the species and ST level [19]. It is based on conventional PCR amplification and sequencing of seven housekeeping genes, either from strains or from plant and insect samples.

Soon after Xf was detected on Mallorca in October 2016, subsequent surveys revealed that the bacterium was widespread in the other islands. Knowledge of the association of the different subspecies with their host plants is useful to better understand $X f$ ecology, and is particularly relevant in cases of new outbreaks or for the description of new hosts, such as was the case of the Balearic Islands. For that, in parallel to the extensive surveys conducted throughout the different islands of the archipelago to highlight $X f$ outbreaks, extension, and host range, an effort was made to type the positive $X f$ samples to the species and ST level by using the conventional MLST protocol [19] or a newly designed nested-MLST approach [20]. This allowed us to determine the presence of three $X f$ subspecies and four STs in the Balearic Islands (Table 1): (i) Xf subsp. fastidiosa ST1, which causes Pierce's disease on grapevines and almond leaf scorch disease (ALSD) in California, recorded only in Mallorca [15,21]; (ii) a new ST of Xf subsp. pauca (ST80) that is found only in Ibiza, mainly on olive trees (O. europaea); and (iii) another novel ST of Xf subsp. multiplex (ST81) 
that is closely related to ST6 and is present in Mallorca and Menorca [15]. In addition, there have been two detections of Xf subsp. multiplex ST7 in Mallorca (Table 1).

The finding of $X f$ in olive trees in the Balearic Islands was the second report of this bacterium on this crop in Europe. This heightened alarms in the olive agricultural sector that was covered by local and national media, being a reason of great concern to mainland Spain. However, the subspecies and STs detected in the Balearic Islands were different to those detected in Apulia, Italy: The subspecies multiplex ST81 was associated to wild olive tree decline in Mallorca; then, the subspecies pauca ST80 was related to olive decline and mortality in Ibiza on November 2016, and three months later the first positive of $X f$ on wild olive trees in Menorca was detected associated to subspecies multiplex ST81.

The genetic resolution at ST-level among $X f$ strains may not permit the identification of closely related but different strains, and it has been shown that strains belonging to the same ST may not be phylogenetically related or share similar traits, such as host plant range [14]. For these reasons, whole-genome sequence data should probably be used when considering $X f$ quarantine, eradication, and containment strategies. Following this reasoning, an effort to obtain genome sequences of representative isolates present in the Balearic Islands was made soon after the first detection in 2016. Thus, the genomes of three isolates of Xf subsp. fastidiosa ST1, collected from Mallorca and several from Xf subsp. multiplex ST81 were obtained $[10,11,22]$. Those publications reported the presence of a $38 \mathrm{~kb}$ plasmid pXFAS_5235, with a high sequence similarity to the conjugative plasmid pXFAS01 from isolate M23 causing ALSD in California. In addition, a close genetic relationship between Mallorcan Xf isolates belonging to ST1 and ST81 and Californian Xf isolates related to Pierce's disease and ALSD was confirmed recently by phylogenetic analysis based on core genomes $[12,15,21]$. Bayesian phylogenetic inference predicted that both Xf subspecies found in Mallorca, fastidiosa ST1 (95\% highest posterior density: 19901997) and multiplex ST81 (95\% highest posterior density: 1991-1998), shared their most recent common ancestors with Californian $X f$ populations associated with almonds and grapevines [15]. In addition, by comparing the core genomes of isolates from Mallorca and Menorca belonging to ST81 we could determine that this ST was introduced to Menorca from Mallorca [15]. These findings have been crucial to disentangle the biogeographic and evolutionary relationships between $X f$ genotypes in the Balearic Islands.

Among the genomes of Majorcan Xf isolates, almost all the genetic recombination detected between the fastidiosa and multiplex subspecies precede their introduction onto the island [12]. This could suggest that the ancestral population had already undergone stabilizing selection, likely as an adaptation to the almond trees in California and thus it would be unlikely that there would be an emergence of new genotypes with different virulence or host ranges in Mallorca. However, we do see a notable risk of disruptive selection if the ST80 strain of subsp. pauca comes into contact with the other subspecies. New recombinants with unpredictable virulence and host ranges could be generated. All phytosanitary efforts should be directed to avoid this risk, although the challenge of detecting new introductions among millions of infected plants is enormous, especially in plants such as the almond tree that can host all three subspecies.

Finally, comparison of the genomes of several isolates of Xf subsp. fastidiosa ST1 and Xf subsp. multiplex ST81 collected from Mallorca from different hosts revealed a little genetic polymorphism within the Mallorcan population (short number of SNPs) as compared to isolates from California from the same subspecies [16]. This pattern is expected to occur for the introduction of a small subset of genotypes from a larger source population into a new area (founder effect), and supports the hypothesis of the introduction of a single or few $X f$ genotypes through infected buds or scions and their subsequent long-distance spread through grafting or vectors across the island.

\section{Pathways of Introductions and Establishment}

$X f$ localization in coastal unconnected areas of the Mediterranean basin (Figure 2) raises questions about the environmental and socio-economic factors explaining its distri- 
bution in Europe. The ornamental plant trade has been proposed as the main pathway of $X f$ introduction and spread within Europe. This view is supported by data of Eurostat that point to a significant volume of potential ornamental host plants being imported from Central America to Europe since 2000 [23]. Although there are no data on the volume of plants imported from America into the Balearic Islands, we do not think this is higher than in other regions of Europe, and nothing makes us think differently for Apulia, Corsica, and Alicante [23]. A recent phylogenetic study showed the close relatedness of the strain ST53 of subsp. pauca responsible for the olive quick decline syndrome in Italy with isolates from Costa Rica [24]. In addition, the same ST53 had been intercepted on ornamental coffee plants imported from Central America [25]. Other interceptions of ornamental plants infected by diverse genetic profiles of $X f$ would confirm the relevance of this pathway [26]. In the case of the Balearic Islands, the ST80 of subsp. pauca has been found only in Ibiza and it is unknown in other areas of the world. Furthermore, whole genome sequences indicate that is a new genotype not previously described, and genetically differentiated from other Xf subsp. pauca strains (L.F. Arias-Giraldo, M. Román, E. Moralejo, B.B. Landa, unpublished results). This suggests a likely introduction through imported ornamental plants. We believe this introduction would have occurred at least one decade ago given the high incidence and spread of ALSD and olive decline in 2012 in Ibiza that can be inferred from images of Google Map Street View. Almost all imported ornamental plants coming to Mallorca are also delivered into garden centers in Menorca and Ibiza, as was demonstrated for the quarantine plant pathogen Phytopthora ramorum [1]. However, surprisingly the ST80 remains known only in Ibiza. The distribution of $X f$ among the islands indicates the strong geographic barrier imposed by the sea, irrespective of the distance between islands. For example, the small island of Formentera only $3.6 \mathrm{~km}$ from Ibiza is still free of $X f$, whereas the ST81 of subsp. multiplex was introduced into Menorca from Mallorca [15] which is $63 \mathrm{~km}$ away. This shows that the likelihood of establishment of an introduction is an odd stochastic event conditioned by factors more related to human activity than natural dispersal. This agrees with the known short-distance dispersal of P. spumarius.

The second main pathway of introductions is likely related to the movement of plant material for breeding purposes and crop improvement programs, such as those implemented in the major almond-producing countries in the 1980s and 1990s. As pointed out in genetic studies on the diversity of the subsp. multiplex in Europe, they share their most recent common ancestors with isolates from California, mainly related to almond leaf scorch disease [12,15]. Furthermore, the introductions of the ST1 (subsp. fastidiosa) and ST81 (subsp. multiplex) into Mallorca from California have been estimated at around 1993, and the likely origins of the strains in Alicante and Corsica are also related to strains of ALSD in California [12,15]. Other introductions such as that of the subsp. fastidiosa in Iran might have followed the same pathway [27]. While the ornamental trade pathway ensures an even distribution of infected plants across Europe, this second pathway of introduction is much more localized, and directly exposes the $X f$ strain to the field, providing many more chances of $X f$ strains becoming established.

A third pathway of $X f$ introduction via infectious insect vectors seems to be less probable. Long-distance transport of infectious vectors hitchhiking on cargo containers associated to plant trade from the Americas into the EU cannot be ruled out. However, it seems highly unlikely this has occurred since, as far as we know, none of the American vectors have become established in Europe. In addition, the number of infectious vectors arriving alive and needed to establish and originate an outbreak in a new area depends on several factors. If a potential primary infection took place in some of the islands by this means, then local vectors could have spread the infection within an island. Finally, inadvertent transportation of vectors in vehicles, boats, or the important ferryboat traffic between the islands may be the cause of the spread of subsp. multiplex ST81 from Mallorca to Menorca. 


\section{Xf subsp. multiplex}

- Xf subsp. fastidiosa

- Xf subsp. pauca

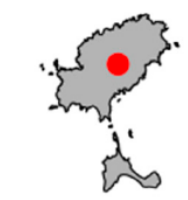

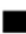

$80 \mathrm{~km}$
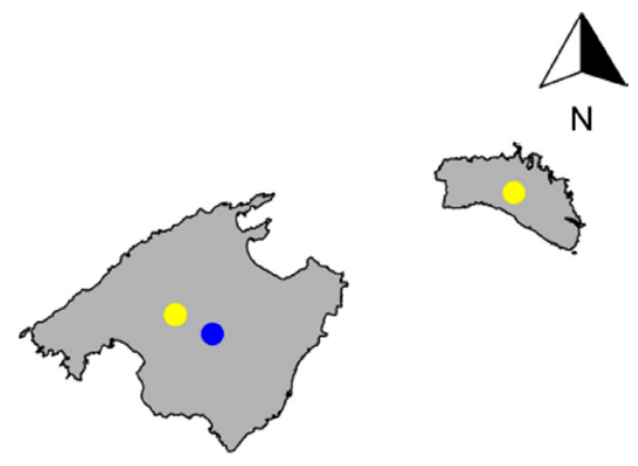

$\mathrm{N}$
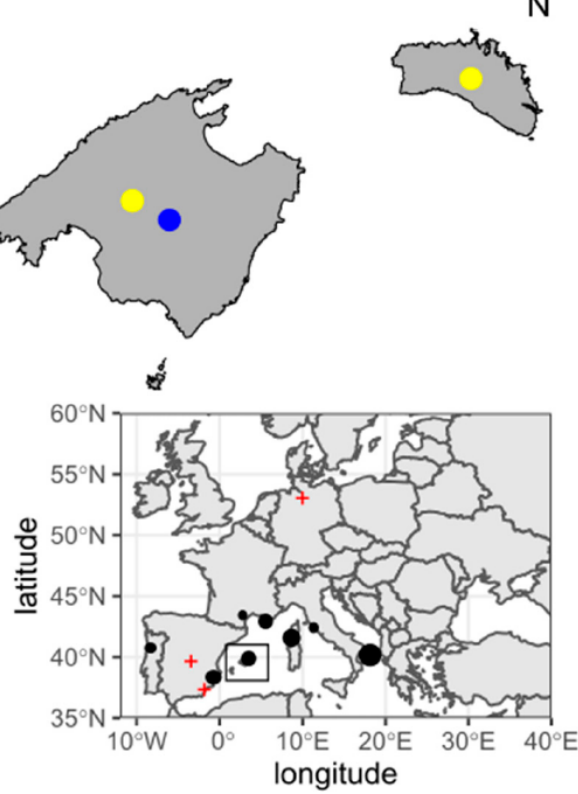

Figure 2. Distribution of $X f$ in the Balearic Islands and Europe. Outbreaks considered eradicated are marked with a red + . All areas where $X f$ is well established (black dots) are less than $50 \mathrm{~km}$ from the coast. Size of circles is proportional to the area affected by the outbreaks.

All the evidence presented above indicates that $X f$ genetic diversity in the Balearic Islands is probably the result of these two main pathways of introduction: the ornamental plant trade and the movement of plant material for breeding purposes and crop improvement programs. However, much uncertainty surrounds the origin of ST7 strains detected only in two samples, Polygala and Prunus dulcis in Mallorca. Until we obtain an isolate and sequence its genome, we can only speculate on their origin, but different hypotheses can be raised: (i) that ST7 was also introduced into Mallorca at the same time as genotypes ST1 and ST81, since this ST has also been identified in almonds (https:/ / pubmlst.org/xfastidiosa/, accessed on 15 January 2021); (ii) that ST7 comes from infected ornamental plants from European nurseries, since ST7 has also been identified in France $[9,12,28]$; (iii) that ST7 is a reminiscent genotype of the founder population from California which very soon evolved into the ST81, as genotypes adapted to wild olive trees.

\section{Crop Diseases}

$X f$ has had a very severe impact on the Mallorcan iconic landscape of flowering almond trees. Between 2010 and 2019 the total surface of almond tree orchards has decreased from 29,789 ha to 11,814 ha (https: / / www.mapa.gob.es/es/estadistica/temas, accessed on 1 December 2020), mainly due to $X f$ infections but also influenced by other socio-economic factors. The almond tree decline began around 2003 at the east of the island. Between 2008 and 2010 the disease was studied, arriving at the conclusion that an assortment of trunk fungal pathogens was associated with the almond decline [14]. After the detection of $X f$, the almond decline has been revisited and the epidemiology reconstructed using updated information: the decline has now been attributed to $X f$ infections [15]. We showed that ALSD symptoms precede any symptoms previously associated to fungi; indeed, $X f$ infection induces a biological drought which activates a number of endophytes living in the bark and wood from a commensal to a necrotroph-pathogenic stage. This synergy remains poorly studied and has not yet been quantified; however, it reminds us how complex and easily misinterpreted the interactions between plants and microorganisms and their ecological function can be. 
A new technique using a combination of dendrochronology and molecular analysis (including MLST and qPCR) has revealed almond infections on growth rings back to 1998 [15]. This simple approach has enabled estimations of the median survival time from $\mathrm{Xf}$ infection to tree collapse of around 14 years, and the frequent observation of trees still alive 20 years after infection. Such large time periods make it difficult to relate a pathogen with symptoms; so, it is understandable that ALSD could be confounded with a general decline due to drought under Mediterranean climates. On the island of Ibiza something similar occurred but in this case the ALSD was caused by the ST80 of subspecies pauca. The extent of the ALSD incidence in Ibiza has not been calculated, but based on our experience in Mallorca we anticipate similar incidences in Ibiza. On the island of Menorca, almond orchards are uncommon but samples from almond trees revealed that they were infected by ST81. Almond trees are the only host that has been infected by the four STs found in the Balearic Islands (Table 1). All these STs are capable of developing ALSD at epidemic levels.

Our reconstruction of the introduction of the ST1 and ST81 assumes that ST1 populations were soon transmitted by P. spumarius from almond orchards to vineyards in Mallorca. PD is currently widespread in vineyards of the island; however, its incidence is highly variable, ranging from 0 to $99 \%$ [21]. Most vineyards following conventional viticulture techniques have retained PD incidence at low levels, with even the viticulturists being unaware of the disease, but PD incidence of over $90 \%$ has been observed in organic vineyards. PD could be very severe locally. Isolates from almond trees and grapevines belonging to ST1 share haplotypes with identical core genomes and their populations are not structured by the hosts, indicating frequent cross infections [16]. Pierce's disease affects at least 23 grapevine cultivars in Mallorca with different severities. It has been shown in inoculation tests that almost all cultivars are susceptible to infection [21]. Vine to vine transmission is predominant in orchards where vector pressure is raised due to relaxed weed and insect control. These epidemiological aspects should be considered in risk assessment so as not to underestimate the spread and economic impact of Pierce's disease if $X f$ is introduced into mainland.

The ST80 of subspecies pauca in Ibiza is probably the main threat to olive trees in mainland Spain. Although it seems less virulent than its pauca-relative ST53 on olive trees in Italy, ST80 causes a deadly dieback too. Olive trees and wild olive trees are both affected. The symptoms are very similar to those of olives in Italy, but the survival times, though not yet estimated with data, seem somehow longer. Thus, during these last four years of monitoring most of the olive trees show severe decline but few have died. Symptoms look like something between the sub-lethal diebacks (no mortality) caused by ST81 of subspecies multiplex on wild olive in Mallorca and Menorca and those of ST53 in Italy (Figure 3). The ST80 also affects other hosts in Ibiza (Table 1). Recently, we have obtained several isolates from olive and almond which are being sequenced to understand their phylogenetic position with respect to other subspecies pauca in the world and their evolutionary trajectory on the island.

An emergent disease affecting fig trees is caused by the ST81 of subspecies multiplex in Mallorca and Menorca. The etiology of the disease has not been yet studied, but the disease seems quite extended and severe enough to justify more attention. Symptoms begin with marginal leaf necrosis and leaf interveinal chlorosis, progressive tip and shoot dieback, and finally tree death several years after infection (Figure 4).

Finally, $X f^{\prime}$ s impact is already changing the agricultural landscape of Mallorca and to a lesser extent that of Ibiza. Almond orchards, a dominant crop of the Mallorcan landscape, are progressively being substituted by open fields and carob orchards. In all conflicts there are losers and winners. Carob trees, so far, have been resistant to the two strains of $X f$ in Mallorca and thus are being intensively planted to replace the almond plantations. In the next decade, the agricultural landscape of Mallorca will be very different to that viewed by former generations. Changes are slow but in the next ten years we will witness the death of almost all the almond trees which are now infected, unless $X f$ resistant or tolerant almond varieties are found. 

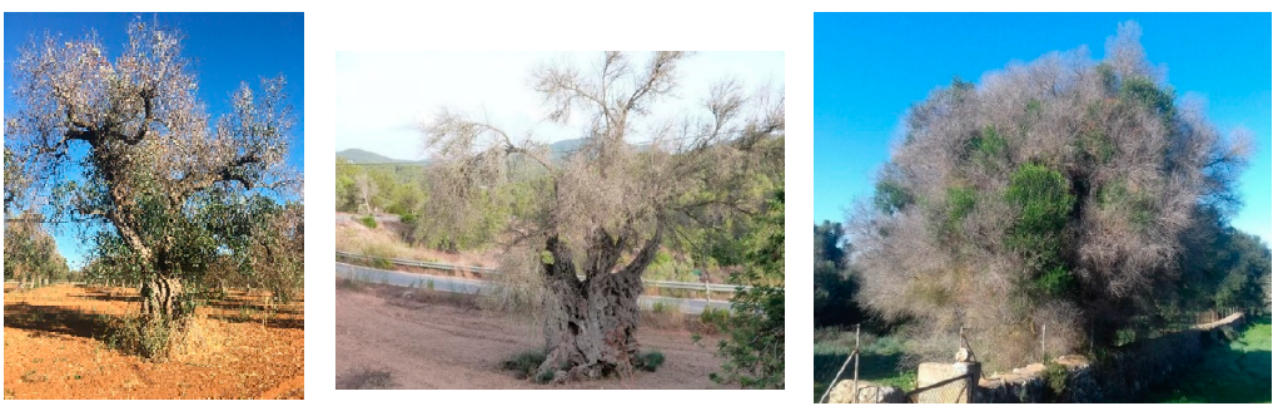

Figure 3. Cultivated olive and wild olive trees infected by different genotypes of $X$. fastidiosa in Europe. Left, olive tree infected by ST53 subsp. pauca in Apulia, Italy; center, dead olive tree infected by ST80, subsp. pauca in Ibiza, Spain; right, wild olive tree showing severe dieback caused by ST81 subsp. multiplex in Mallorca.

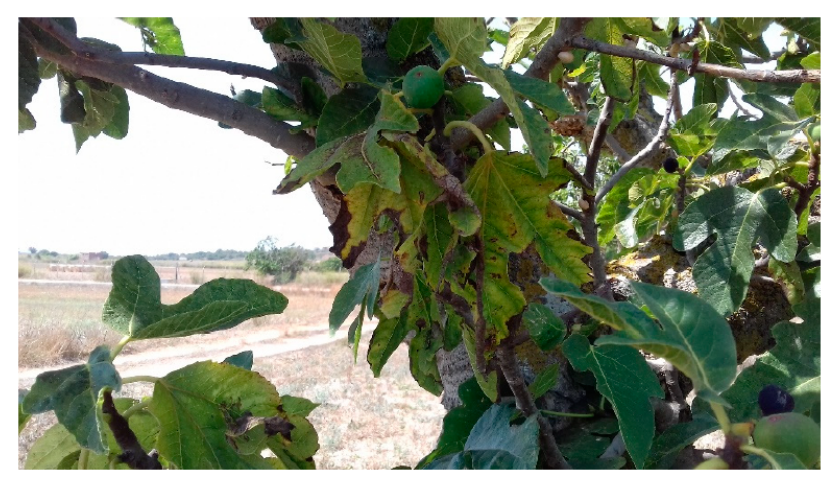

Figure 4. Leaf symptoms of fig tree (Ficus carica) infected by multiplex ST81.

\section{Transmission and Crop Disease Management}

The insect Philaenus spumarius seems to be the main vector of ALSD and PD in the Balearic Islands [15,21]. Transmission vine-to-vine, almond-to-almond and almond-tovine has been demonstrated in greenhouse transmission experiments $[15,21]$, and cross transmission experiments with wild olive trees are underway. While P. spumarius is the most prevalent vector, other potential vectors have been captured with much less frequency, such as Neophilaenus campestris and Neophilaenus lineatus. In Mallorca, DNA of both Xf subsp. fastidiosa and $X f$ subsp. multiplex has been found in P. spumarius specimens collected in a vineyard and its surroundings $[15,20]$. Weed and pest management have a strong influence on vector populations and hence on disease transmission by $\mathrm{Xf}$, although there is not necessarily a connection between vector number and vector transmission. This was one of the main ideas put forward by $X f$ investigators from the USA and Brazil to Europeans during the two international Xylella conferences held by the European Food Safety Authority (EFSA). Unlike the epidemiology of PD and ALSD in California, annual and perennial weeds seem to play a minor role, if any, as a pathogen reservoir in almond orchards and vineyards of the Balearic Islands. A similar situation has been reported for the olive quick disease syndrome in Apulia, Italy, where the role of weeds in $X f$ transmission seems to be negligible [29]. None of the 57 annual and biannual plant species analyzed ( $n=149$ samples) that are usually associated with agriculture were positive for $X f$, despite Convolvulus arvensis, Erodium spp., Portulaca oleracea, Heliotropium europaeum, and Sorghum halepense are listed as known hosts [18]. These observations raise the question of why weeds escape infection while the larval stage of $P$. spumarius develops and feeds on them. A reasonable explanation would be that the lifecycle of weeds in the Balearic Islands is regulated by the availability of soil water, whereas $X f$ growth depends on temperatures above $20^{\circ} \mathrm{C}$ [30]. These two limiting factors for each group do not juxtapose except in irrigated fields, thereby P. spumarius adults are presumably $X f$-free when they move from weeds to the tree canopy in May. 


\section{Pathogenicity, Host Range, and Phylogenetic Signal}

The mechanism behind pathogen-host specificity in $X f$ remains unresolved [31]. In the American continent, $X f$ causes economically significant diseases on non-native fruit crops such as coffee (Africa), citrus (Asia), almond (Asia), grapevine (Europe), peach (Asia), and olive (Europe), whereas the native wood crops, avocado, chocolate tree, rubber, vanilla, cherimoya, and papaya are not reported as hosts [32]. Non-coevolved hosts thus would seem to be more vulnerable to $X f$-induced diseases. Nonetheless, this does not need to be exactly so. There is increasing evidence that only a small fraction of non-American plants develop disease when exposed to the pathogen. For example, of the 1,729 native plant taxa on the Balearic Islands only 28 plant species out of 454 taxa examined were positive to Xf during these four years (Table 1; Figure 5), whilst in the case of Corsica only 30 hosts were reported out of 2500 plant species comprising its flora [9]. Ecological and geographic barriers might have excluded part of the Balearic flora from $\mathrm{Xf}$ exposure; however, reasonably the great bulk of plants, especially in ruderal and scrub plant communities, might have been in contact with infected insect vectors over these 20 years. The same pattern would be expected for Corsica, given the widespread occurrence of $X f$-infected P. spumarius throughout the island [33]. Further surveys are needed to elucidate the full host range extent in the Balearic Islands. For the time being, $O$. europaea var. sylvestris is by large the main wild host, and other hosts composing wild olive trees and shrubs such as rosemary, Cistus spp., or lavender could have a big impact in the Balearic Islands (Table 1).

A

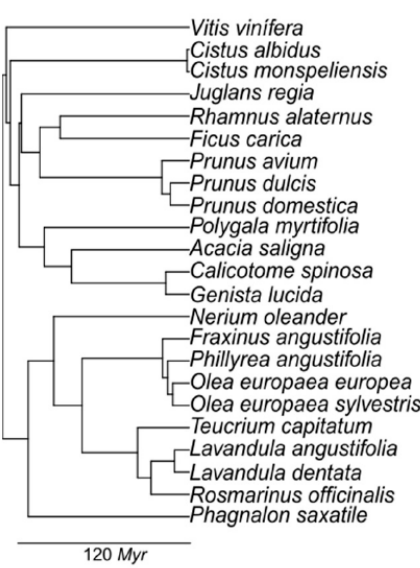

B

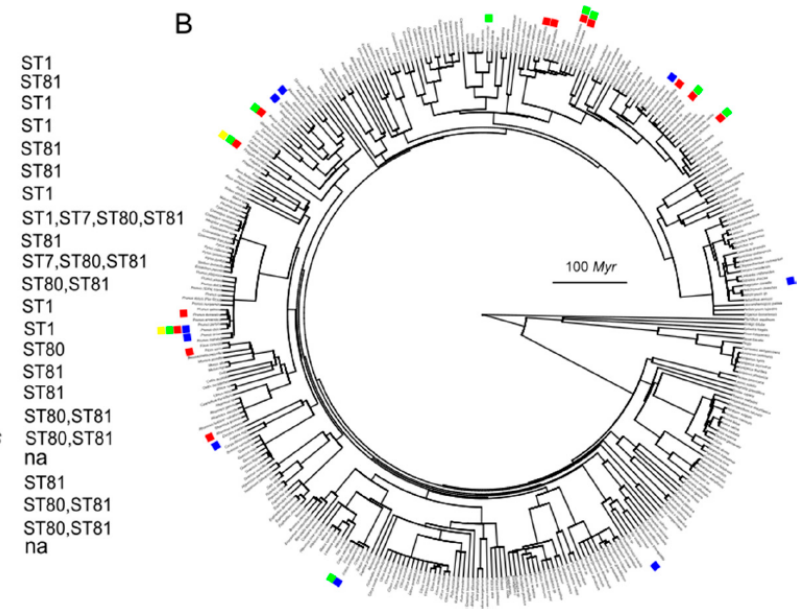

Figure 5. Phylogenetic signal in host range of Xf different STs (clonal lineages) detected in the Balearic Islands between October 2016 and February 2020. (A) Phylogenetic distances of $X f$ hosts. Each of the ST shares hosts that evolutionarily diverged for $>100 \mathrm{Myr}$ (million years). (B) Phylogenetic tree including all plant species $(n=348)$ analyzed for $X f$ until February 2020. Blue square, ST1; red square, ST81; green square, ST80; and yellow square, ST7.

The phylogenetic signal in host ranges of pathogens is increasingly used as a tool for predicting potential new hosts in risk assessments [34]. It is based on a coevolution principle in which closely related species share more similar traits involved in host-pathogen interactions than evolutionary distant ones. Thus, the host range of a particular genetic lineage (e.g., ST) can predict the likelihood of infection on genetically related hosts in other areas where it has been introduced [35]. Based on this principle, the presence of ALSD and PD was anticipated in Mallorca in the spring of 2017 before any field symptoms were observed after receiving confirmation that the MLST profiles of isolates from P. dulcis and Polygala sp. were identical to those causing ALSD and PD in California. We used the database of plants analyzed for $X f$ in the Balearic Islands to investigate the relationship between the phylogenetic distance and the likelihood of being infected by a particular ST. No apparent phylogenetic signal was observed for clades diverging over 100 million 
years (Myr), although hosts tended to cluster together in more recent divergent genetic lineages (Figure 5). For example, ST1 can infect $V$. vinifera-Genista lucida, with a genetic divergence $>100 \mathrm{Myr}$; ST80 can infect P. dulcis-O. europaea $>100 \mathrm{Myr}$; and ST81 can infect Cistus monspeliensis-Rosmarinus officinalis $>100 \mathrm{Myr}$, whereas each ST tends to cluster in botanical families such as Oleaceae, Leguminosae or Lamiaceae (Figure 4). Recently, the phylogenetic relationship among $55 \mathrm{Xf}$ sequence types and their known hosts was tested for co-evolutionary congruence, obtaining no significant co-evolutionary fit [35]. Other results indeed would be surprising, since by definition co-evolution occurs only between organisms interacting in time and space and, as we explained before, most of the 579 listed $X f$ hosts are non-American plants. In addition, the evolutionary history of the formation scales of plants and Xf differ in several Myr [36]. In general terms, we conclude that the likelihood of each $X f$ genetic lineage sharing hosts does not decline continuously as a function of evolutionary distance, and this relationship is erratic.

The frontiers between agriculture and wild landscape in the Balearic Islands are frequently diluted by the presence of the widespread wild olive trees as a primary competitive colonizer of uncultured soils. Wild olive trees serve in many instances as corridor species connecting agricultural settlements with scrub vegetation and forests, and thus are prone to $X f$ exposure. Therefore, analyzing the results of all plants tested, whether positives or negatives, adds new insights into the host-range of each $X f$ genetic group. For example, 244 samples of Quercus ilex were analyzed in the Balearic Islands and all tested negative for $X f$, despite oak stands live sympatrically with wild olive trees and in several of the sampled locations adjacent to almond orchards where 100\% ALSD incidence is common. Moreover, no symptoms were obtained when $Q$. ilex samplings were inoculated with isolates of ST1 and ST81 during a two-year assay, confirming that holm oak is not a host for these strains (LOSVIB, unpublished results). There seems to be a strong genetic barrier to infection of holm oaks by strains ST1 and ST81, since the vector P. spumarius is frequently captured in their canopy. Less is known about the resistance of holm oaks to strain ST80 of subspecies pauca, since holm oaks are very scarce in Ibiza. The same can be said about Aleppo pine ( $n=41$ samples all negative), with respect to its resistance to $X f$ which together with oaks constitute the main forests in the Balearic Islands. Other important trees and shrubs species common on the three islands and thus which have been exposed to the genetic spectrum of Xf during many years such as Ulmus minor $(n=264)$, Pistacia lentiscus $(n=279)$, Myrtus communis $(n=129)$, Juniperus oxycedrus $(n=68)$ and Juniperus phoenicia $(n=83)$ seem to be non-hosts to the three $X f$ sequence types detected in Mallorca. In addition, we can claim, with high confidence, that Citrus spp. ( $n=793$ samples analyzed) and carob tree $(n=37)$ also seem to be non-hosts to the $X f$ genotypes found in the Balearic Islands.

\section{8. $X f$-Water Relationship}

Perhaps the main reason why $X f$ was overlooked for so many years in the Balearic Islands is the overlap between drought and $X f$-induced symptoms during summer. Years with wetter late-springs correlate with a delay of the onset of ALSD symptoms and milder severity [15]. Similar effects of late-spring rain on decreasing disease severity have also been observed for wild olive trees in Mallorca in 2017, 2018 and 2019. By contrast, years with drier springs exhibit more severe symptoms, increasing the perception of landscape drought.

The effect of drought on $X f$ behavior within the plant vascular system is not well understood, though branch and crown diebacks in woody hosts seem to be more severe in drier climates, such as the Mediterranean climate. The large differences reported on ALSD incidence and mortality in irrigated almond orchards in California (average $<2 \%$ ) compared to those in rainfed almond fields in Mallorca (>78\%) [21], suggest that stomatal conductance plays a significant role in $X f$ colonization and thus in its transmission. Furthermore, the fact that almond irrigated fields in Mallorca are scarcely affected by Xf as occurs in California supports the view that irrigated plants reduce disease expression and likely transmission between trees within and among orchards. Similarly, PD severity 
in vineyards increases with drought in California both in the field and under controlled experiments [37]; although the effect of drought on infected grapevines seems to be lesser than on almonds, since even well-irrigated grapevines become infected and express disease. In recent inoculation experiments, 29 out of 30 rootstock-scion combinations irrigated throughout the experiment to soil field capacity developed PD symptoms irrespective of the soil moisture [21]. Understanding why severity is modulated by water potential in so many hosts while not in others could provide interesting clues for understanding the mechanism that triggers $X f$ from a 'planktonic' lifestyle (commensal endophyte) to a sticky pathogenic stage [38].

The relationship between water and disease epidemiology could be even more complex. It has been shown that the ALSD progress curve entered in the exponential stage between 2004 and 2010, the extended period of wet springs favoring almond tree productivity [15]. Spring precipitation might be conducive to higher populations of P. spumarius and other potential vectors thus increasing the likelihood of transmission. In turn, wet springs usually correlate with a decrease in the mean temperature that slows $X f$ multiplication within the plant. However, the effect of climate conditions on the population dynamics of the vector and the pathogen within the hosts remains poorly studied.

\section{Conclusions}

After Xf was first detected in October of 2016, a debate took place between the European Commission and the Balearic Government regarding the need to implement eradication or contingency measures. Retrospectively, after more than four years of huge sampling effort and research, it has been shown that neither of those proposed measures was epidemiologically sound, since the pathogen was already widespread and established in the fields for several decades. The reconstruction of the landscape epidemiology of $X f$ in the Balearic Islands, specially concerning that of PDs and ALSD, has important implications for European plant health policy by calling into question the adequacy of eradication and contingency strategies without any prior investigation into the epidemiological history of the outbreaks that are intended to be contained.

Author Contributions: E.M. and B.B.L., conceptualization and writing of manuscript; E.M., preparation of Figures; F.A., A.P., P.A.G., B.Q., A.U., J.d.D.G., O.B., A.J., and J.R., field sampling; D.O., A.N., M.M., M.P.V.-A., C.O.-G., and M.G., laboratory analysis and molecular identification; D.B., insect identification; M.P.V.-A., C.O.-G., and B.B.L., sampling and $X f$ typing; E.M., B.B.L., and E.M.-N., revision and editing of manuscript; D.O., A.J., and B.B.L., project administration and funding. All authors have read and agreed to the published version of the manuscript.

Funding: This work was partially funded by projects XF-ACTORS (Xylella fastidiosa Active Containment Through a Multidisciplinary-Oriented Research Strategy; grant 727987 from the European Union's Horizon 2020 Framework Research Programme), ERTA2017-00004-02 and E-RTA2017-0000404 (Desarrollo de estrategias de erradicación, contención y control de X. fastidiosa en España) from 'Programa Estatal de I + D + I Orientada a los Retos de la Sociedad of the Spanish Government' and FEDER), the Spanish olive oil Interprofesional and the Ministry of Agriculture, Fisheries and Food and the Project ITS2017-095 from 'Consejeria de Medio Ambiente, Agricultura y Pesca' from the Balearic Islands, Spain. M.P.V-A. was a recipient of a PhD fellowship from Intramural Project 201840E111 from CSIC.

Institutional Review Board Statement: Not applicable.

Informed Consent Statement: Not applicable.

Data Availability Statement: Data sharing is not applicable to this article.

Acknowledgments: We thank M. Montes-Borrego IAS-CSIC for his work on typing the Xf samples, and the Thematic Interdisciplinary Platform on Xylella from CSIC (PTI-SolXyl) for its support.

Conflicts of Interest: The authors declare no conflict of interest. 


\section{References}

1. Moralejo, E.; Pérez-Sierra, A.M.; Álvarez, L.A.; Belbahri, L.; Lefort, F.; Descals, E. Multiple alien Phytophthora taxa discovered on diseased ornamental plants in Spain. Plant Pathol. 2009, 58, 100-110. [CrossRef]

2. Jung, T.; Orlikowski, L.; Henricot, B.; Abad-Campos, P.; Aday, A.G.; Aguín Casal, O.; Bakonyi, J.; Cacciola, S.O.; Cech, T.; Chavarriaga, D.; et al. Widespread Phytophthora infestations in European nurseries put forest, semi-natural and horticultural ecosystems at high risk of Phytophthora diseases. For. Pathol. 2016, 16, 134-163. [CrossRef]

3. Santini, A.; Ghelardini, L.; de Pace, C.; Desprez-Loustau, M.L.; Capretti, P.; Chandelier, A.; Cech, T.; Chira, D.; Diamandis, S.; Gaitniekis, T.; et al. Biogeographical patterns and determinants of invasion by forest pathogens in Europe. New Phytol. 2013, 197, 238-250. [CrossRef]

4. Brasier, C.M. The biosecurity threat to the UK and global environment from international trade in plants. Plant Pathol. 2008, 57, 792-808. [CrossRef]

5. Stergiopoulos, I.; Gordon, T.R. Cryptic fungal infections: The hidden agenda of plant pathogens. Front. Plant Sci. 2014, 5, 506. [CrossRef]

6. Waage, J.; Mumford, J. Agricultural biosecurity. Philos. Trans. R. Soc. B Biol. Sci. 2008, 363, 863-876. [CrossRef]

7. Berisha, B.; Chen, Y.D.; Zhang, G.Y.; Xu, B.Y.; Chen, T.A. Isolation of Peirce's disease bacteria from grapevines in Europe. Eur. J. Plant Pathol. 1998, 104, 427-433. [CrossRef]

8. Saponari, M.; Boscia, D.; Altamura, G.; Loconsole, G.; Zicca, S.; D’Attoma, G.; Morelli, M.; Palmisano, F.; Saponari, A.; Tavano, D.; et al. Isolation and pathogenicity of Xylella fastidiosa associated to the olive quick decline syndrome in southern Italy. Sci. Rep. 2017, 7, 1-13. [CrossRef]

9. Denancé, N.; Legendre, B.; Briand, M.; Olivier, V.; de Boisseson, C.; Poliakoff, F.; Jacques, M.A. Several subspecies and sequence types are associated with the emergence of Xylella fastidiosa in natural settings in France. Plant Pathol. 2017, 66, 1054-1064. [CrossRef]

10. Landa, B.B.; Velasco-Amo, M.P.; Marco-Noales, E.; Olmo, D.; López, M.M.; Navarro, I.; Monterde, A.; Barbé, S.; Montes-Borrego, M.; Román-Écija, M.; et al. Draft Genome Sequence of Xylella fastidiosa subsp. fastidiosa Strain IVIA5235, Isolated from Prunus avium in Mallorca Island, Spain. Microbiol. Resour. Announc. 2018, 7, e01222-18.

11. Olmo, D.; Nieto, A.; Adrover, F.; Urbano, A.; Beidas, O.; Juan, A.; Marco-Noales, E.; López, M.M.; Navarro, I.; Monterde, A.; et al. First detection of Xylella fastidiosa infecting cherry (Prunus avium) and Polygala myrtifolia plants in Mallorca Island Spain. Plant Dis. 2017, 101, 1820. [CrossRef]

12. Landa, B.B.; Castillo, A.I.; Giampetruzzi, A.; Kahn, A.; Román-Écija, M.; Velasco-Amo, M.P.; Navas-Cortés, J.A.; Marco-Noales, E.; Barbé, S.; Moralejo, E.; et al. Emergence of a Plant Pathogen in Europe Associated with Multiple Intercontinental Introductions. Appl. Environ. Microbiol. 2020, 86, e01521-19. [CrossRef]

13. Soubeyrand, S.; de Jerphanion, P.; Martin, O.; Saussac, M.; Manceau, C.; Hendrikx, P.; Lannou, C. Inferring pathogen dynamics from temporal count data: The emergence of Xylella fastidiosa in France is probably not recent. New Phytol. 2018, 219, 824-836. [CrossRef]

14. Gramaje, D.; Agustí-Brisach, C.; Pérez-Sierra, A.; Moralejo, E.; Olmo, D.; Mostert, L.; Damm, U.; Armengol, J. Fungal trunk pathogens associated with wood decay of almond trees on Mallorca (Spain). Persoonia Mol. Phylogeny Evol. Fungi 2012, $28,1-13$. [CrossRef]

15. Moralejo, E.; Gomila, M.; Montesinos, M.; Borràs, D.; Pascual, A.; Nieto, A.; Adrover, F.; Gost, P.A.; Seguí, G.; Busquets, A.; et al. Phylogenetic inference enables reconstruction of a long-overlooked outbreak of almond leaf scorch disease (Xylella fastidiosa) in Europe. Commun. Biol. 2020, 3, 1-13. [CrossRef]

16. Harper, S.J.; Ward, L.I.; Clover, G.R.G. Development of LAMP and Real-Time PCR Methods for the Rapid Detection of Xylella fastidiosa for Quarantine and Field Applications. Phytopathology 2010, 100, 1282-1288. [CrossRef]

17. Francis, M.; Lin, H.; Rosa, J.C.-L.; Doddapaneni, H.; Civerolo, E.L. Genome-based PCR Primers for Specific and Sensitive Detection and Quantification of Xylella fastidiosa. Eur. J. Plant Pathol. 2006, 115, 203-213. [CrossRef]

18. Bragard, C.; Dehnen-Schmutz, K.; di Serio, F.; Gonthier, P.; Jacques, M.; Jaques Miret, J.A.; Justesen, A.F.; MacLeod, A.; Magnusson, C.S.; Milonas, P.; et al. Update of the Scientific Opinion on the risks to plant health posed by Xylella fastidiosa in the EU territory. EFSA J. 2019, 17, 5665. [CrossRef]

19. Yuan, X.; Morano, L.; Bromley, R.; Spring-Pearson, S.; Stouthamer, R.; Nunney, L. Multilocus Sequence Typing of Xylella fastidiosa Causing Pierce's Disease and Oleander Leaf Scorch in the United States. Phytopathology 2010, 100, 601-611. [CrossRef]

20. Cesbron, S.; Dupas, E.; Beaurepère, Q.; Briand, M.; Borrego, M.M.; Velasco Amo, M.P.; Landa, B.; Jacques, M.-A. Development of a Nested-MultiLocus Sequence Typing approach for a highly sensitive and specific identification of Xylella fastidiosa subspecies directly from plant samples. Agronomy 2020, 10, 1099. [CrossRef]

21. Moralejo, E.; Borràs, D.; Gomila, M.; Montesinos, M.; Adrover, F.; Juan, A.; Nieto, A.; Olmo, D.; Seguí, G.; Landa, B.B. Insights into the epidemiology of Pierce's disease in vineyards of Mallorca, Spain. Plant Pathol. 2019, 68, 1458-1471. [CrossRef]

22. Gomila, M.; Moralejo, E.; Busquets, A.; Segui, G.; Olmo, D.; Nieto, A.; Juan, A.; Lalucat, J. Draft genome resources of two strains of Xylella fastidiosa XYL1732/17 and XYL2055/17 isolated from Mallorca vineyards. Phytopathology 2019, 109, 222-224. [CrossRef]

23. EFSA Panel on Plant Health. Scientific Opinion on the risks to plant health posed by Xylella fastidiosa in the EU territory, with the identification and evaluation of risk reduction options. EFSA J. 2015, 13, 3989. [CrossRef] 
24. Giampetruzzi, A.; Saponari, M.; Loconsole, G.; Boscia, D.; Savino, V.N.; Almeida, R.P.P.; Zicca, S.; Landa, B.B.; Chacón-Diaz, C.; Saldarelli, P. Genome-Wide Analysis Provides Evidence on the Genetic Relatedness of the Emergent Xylella fastidiosa Genotype in Italy to Isolates from Central America. Phytopathology 2017, 107, 816-827. [CrossRef]

25. Bergsma-Vlami, M.; van de Bilt, J.L.J.; Tjou-Tam-Sin, N.N.A.; Helderman, C.M.; Gorkink-Smits, P.P.M.A.; Landman, N.M.; van Nieuwburg, J.G.W.; van Veen, E.J.; Westenberg, M. Assessment of the genetic diversity of Xylella fastidiosa in imported ornamental Coffea arabica plants. Plant Pathol. 2017, 66, 1065-1074. [CrossRef]

26. Loconsole, G.; Saponari, M.; Boscia, D.; D'Attoma, G.; Morelli, M.; Martelli, G.P.; Almeida, R.P.P. Intercepted isolates of Xylella fastidiosa in Europe reveal novel genetic diversity. Eur. J. Plant Pathol. 2016, 146, 85-94. [CrossRef]

27. Amanifar, N.; Taghavi, M.; Izadpanah, K.; Babaei, G. Isolation and pathogenicity of Xylella fastidiosa from grapevine and almond in Iran. Phytopathol. Mediterr. 2014, 53, 318-327.

28. Denancé, N.; Briand, M.; Gaborieau, R.; Gaillard, S.; Jacques, M.-A. Identification of genetic relationships and subspecies signatures in Xylella fastidiosa. BMC Genom. 2019, 20, 239. [CrossRef]

29. Cornara, D.; Saponari, M.; Zeilinger, A.R.; de Stradis, A.; Boscia, D.; Loconsole, G.; Bosco, D.; Martelli, G.P.; Almeida, R.P.P.; Porcelli, F. Spittlebugs as vectors of Xylella fastidiosa in olive orchards in Italy. J. Pest Sci. 2017, 90, 521-530. [CrossRef]

30. Feil, H.; Purcell, A.H. Temperature-Dependent Growth and Survival of Xylella fastidiosa in Vitro and in Potted Grapevines. Plant Dis. 2001, 85, 1230-1234. [CrossRef]

31. Almeida, R.P.P.; Nunney, L. How Do Plant Diseases Caused by Xylella fastidiosa Emerge? Plant Dis. 2015, 99, 1457-1467. [CrossRef]

32. EFSA. Update of the Xylella spp. host plant database. EFSA J. 2018, 16, e05408.

33. Cruaud, A.; Gonzalez, A.A.; Godefroid, M.; Nidelet, S.; Streito, J.C.; Thuillier, J.M.; Rossi, J.P.; Santoni, S.; Rasplus, J.Y. Using insects to detect, monitor and predict the distribution of Xylella fastidiosa: A case study in Corsica. Sci. Rep. 2018, 8, 1-13. [CrossRef]

34. Gilbert, G.S.; Magarey, R.; Suiter, K.; Webb, C.O. Evolutionary tools for phytosanitary risk analysis: Phylogenetic signal as a predictor of host range of plant pests and pathogens. Evol. Appl. 2012, 5, 869-878. [CrossRef]

35. Sicard, A.; Zeilinger, A.R.; Vanhove, M.; Schartel, T.E.; Beal, D.J.; Daugherty, M.P.; Almeida, R.P.P. Xylella fastidiosa: Insights into an Emerging Plant Pathogen. Annu. Rev. Phytopathol. 2018, 56, 181-202. [CrossRef]

36. Vanhove, M.; Retchless, A.C.; Sicard, A.; Rieux, A.; Coletta-Filho, H.D.; de La Fuente, L.; Stenger, D.C.; Almeida, R.P.P. Genomic diversity and recombination among Xylella fastidiosa subspecies. Appl. Environ. Microbiol. 2019, 85, 85. [CrossRef]

37. Choi, H.-K.; Iandolino, A.; da Silva, F.G.; Cook, D.R. Water Deficit Modulates the Response of Vitis vinifera to the Pierce's Disease Pathogen Xylella fastidiosa. Mol. Plant Microbe Interact. 2013, 26, 643-657. [CrossRef]

38. Chatterjee, S.; Almeida, R.P.P.; Lindow, S. Living in two Worlds: The Plant and Insect Lifestyles of Xylella fastidiosa. Annu. Rev. Phytopathol. 2008, 46, 243-271. [CrossRef] 